\title{
Studies on Proximate Composition, Mineral and Total Phenolic Content of Yogurt Bites Enriched with Different Plant Raw Material
}

\author{
Jurgita Kulaitienè, Nijolè Vaitkevičienė * ${ }^{*}$ and Dovilè Levickienè
}

Citation: Kulaitienè, J.; Vaitkevičienè, N.; Levickienè, D. Studies on Proximate Composition, Mineral and Total Phenolic Content of Yogurt Bites Enriched with Different Plant Raw Material. Fermentation 2021, 7, 301. https://doi.org/10.3390/fermentation 7040301

Academic Editor: Senaka Ranadheera

Received: 16 November 2021

Accepted: 9 December 2021

Published: 9 December 2021

Publisher's Note: MDPI stays neutral with regard to jurisdictional claims in published maps and institutional affiliations.

Copyright: (C) 2021 by the authors Licensee MDPI, Basel, Switzerland. This article is an open access article distributed under the terms and conditions of the Creative Commons Attribution (CC BY) license (https:// creativecommons.org/licenses/by/ $4.0 /)$.
Department of Plant Biology and Food Sciences, Vytautas Magnus University Agriculture Academy, Donelaičio Str. 58, 44248 Kaunas, Lithuania; jurgita.kulaitiene@vdu.lt (J.K.); dovile.levickiene@vdu.lt (D.L.)

* Correspondence: nijole.vaitkeviciene@vdu.lt; Tel.: +370-(37)-752-326

\begin{abstract}
Yogurt products are consumed by millions of people every day. Consumers' priority for ready-to-eat yogurt snacks enriched with various plant raw materials have increased each year. Therefore, the aim of this study was to prepare freeze-dried yoghurt bites with the addition of powders of beetroot, mulberry leaves, nettle leaves and rosehip fruit and to investigate these raw materials' influence on the proximate composition, mineral and total phenolic content. The moisture, protein, fat, carbohydrate and sugar content of the yogurt bites were established using standard methods: mineral composition-using an inductively coupled plasma mass spectrometer (ICPMS); total phenolic content-by the spectrophotometric method. The results demonstrated that the addition of different raw material powders to the formulation of yogurt bites had no significant influence on carbohydrate, protein and total fat amounts. However, the incorporation of powders of beetroot, mulberry leaves, nettle leaves and rosehip fruit in yogurt bites allowed a significant increase of the amounts of all investigated minerals and total phenolic content of the manufactured bites. Among all investigated yogurt bites, the highest amounts of $\mathrm{K}, \mathrm{P}, \mathrm{Mg}, \mathrm{Fe}$ and $\mathrm{Zn}$ were determined for yogurt bites enriched with nettle leaves. In conclusion, the enrichment of yogurt bites with freeze-dried plant raw material powders can increase amounts of selected minerals and total phenolic content.
\end{abstract}

Keywords: yogurt bites; nettle leaves; mulberry leaves; rosehip fruit; beetroot; calcium; potassium; phosphorus; iron

\section{Introduction}

With the intense development of the food industry, a lot of products of the ready-to-eat type are being produced for the customer and the amount of such produced food products is increasing rapidly. People that are interested in healthy and functional food enriched with additional vitamins, minerals, bioactive ingredients and probiotic bacteria grows each year [1]. Such products are gaining more widespread popularity and acceptance throughout the developed world. Therefore, functional products need to satisfy advanced product properties: extended shelf life, attractive market appearance, appropriate and attractive taste, smell and colour, and maintain these properties during transportation and storage time.

Greek yoghurt is one of the most popular fermented milk products. It is a great source of high-quality protein, calcium, phosphorus and potassium, and various vitamins [2-4], but it is considered a poor source of phenolic compounds. Raw materials such as berries, vegetables or leaves are a promising source of phenolic components [5]. However, yoghurt shelf life is short compared to other dairy products such as cheese. In addition, the yoghurt requires appropriate temperature conditions and refrigeration equipment [6]. Currently, the world market of freeze-dried yoghurt snacks/bites is fragmented. Yoghurt snacks are mostly enriched with berries and fruit concentrates (strawberries, raspberries, blueberries, 
blackberries, peaches, etc.). There is no such yoghurt snack or bite which is enriched with nettle and mulberry leaves, or beetroot and rosehip powder. Nettle (Urtica dioica L.) has a long history of usage and is currently receiving attention as a source of fibre and alternative medicine. In many cultures, nettle is also eaten as a leafy vegetable. The entire plant of nettle can be utilised for a variety of applications, including food, fodder, medicinal, cosmetics, biodynamic agriculture and textile manufacture [7,8]. Chlorophyll, carotenoids, vitamins, proteins, lipids, carbohydrates, organic acids, minerals and trace elements are abundant in the leaves of nettles [9-12]. In many regions of the world, beetroot (Beta vulgaris L.) is a traditional and popular vegetable. Beetroot includes a high concentration of biologically active components such as phenolic compounds, betalains, carotenoids, B-vitamins ( $\mathrm{B}_{1}, \mathrm{~B}_{2}, \mathrm{~B}_{3}, \mathrm{~B}_{6}$ and $\left.\mathrm{B}_{12}\right)$, fibre and low-energy carbohydrates [13]. Furthermore, manganese, potassium, phosphorus, magnesium, sodium, iron, copper, zinc, boron, silica and selenium are all minerals found in beetroots [14-16]. Beetroot is produced for food rather than for the manufacturing of sugar. Sucrose is the primary sugar in beets, with small levels of glucose and fructose [17]. Rose plants (Rosa spp.) produce fruits that are high in polyphenols, vitamins $\mathrm{A}, \mathrm{C}$ and $\mathrm{E}$, essential fatty acids, galactolipid, minerals $(\mathrm{Ca}, \mathrm{Mg}, \mathrm{K}, \mathrm{S}, \mathrm{Si}, \mathrm{Se}, \mathrm{Mn}$ and $\mathrm{Fe})$ and other bioactive components [18,19]. Due to its chemical content and pharmacological properties, the white mulberry plant (Morus alba L.) is one of the traditional herbs that has been use in medicine since ancient times. Mulberry leaves have been established as a high-protein, high-carbohydrate, high-vitamin and highdietary fibre food source [20-22]. Additionally, the mulberry leaves contain a variety of macroelements. Mineral elements play important roles in biological reactions and have structural functions [20,23-25].

As the demand for healthier food products with health-promoting effects has been increasing significantly worldwide, consequently, the incorporation of lyophilised raw material powder in yogurt can be a popular approach to increase the phenolic and mineral element content of the product. Therefore, the purpose of this research is to prepare freeze-dried yoghurt bites with the addition of powders of beetroot, mulberry leaves, nettle leaves and rosehip fruit, and to investigate the influence of these plant raw materials on the proximate composition, mineral and total phenolic content of the final product.

\section{Materials and Methods}

\subsection{Materials}

The plant raw materials were collected in 2019 from spring to autumn. White mulberry (Morus alba) leaves were collected in June, and nettle (Urtica dioica) leaves in March, on an organic farm in Kaunas district, Lithuania $\left(54^{\circ} 53^{\prime} 50^{\prime \prime}\right.$ N 23 $53^{\prime} 10^{\prime \prime}$ E). Rosehip (Rosa rugosa) fruits were harvested in August, and red beetroot (Beta vulgaris) in the end of September at an organic farm in Pakruojis district, Lithuania ( $\left.56^{\circ} 10^{\prime} 29.0^{\prime \prime} \mathrm{N} 23^{\circ} 49^{\prime} 02.6^{\prime \prime} \mathrm{E}\right)$. Collected raw materials were frozen at $-35^{\circ} \mathrm{C}$ and lyophilised using a Freeze-Drying Plant Sublimator (ZIRBUS technology GmbH, Bd Grund, Germany). The samples were lyophilised for $48 \mathrm{~h}$, then were milled (Grindomix GM 200, Retsch GmbH, Haan, Germany), their chemical composition determined in dry matter (DM) (Table 1) and stored in sealed containers at $5{ }^{\circ} \mathrm{C}$ in the dark until yogurt bites preparation.

Greek-style yogurt was purchased at local supermarkets in the city of Kaunas (Lithuania). Nutrition facts of Greek-style yogurt are shown in Table 2.

\subsection{Yogurt Bites Preparation}

In this research, the experiment consisted of 5 treatments as follows (Figure 1):

1. Control (yogurt bites without plant raw materials);

2. Yogurt bites with $1 \%$ rosehip fruit powder;

3. Yogurt bites with $1 \%$ nettle leaves powder;

4. Yogurt bites with $1 \%$ mulberry leaves powder;

5. Yogurt bites with $1 \%$ beetroot powder. 
Table 1. Chemical composition of freeze-dried plant raw material powders, DM.

\begin{tabular}{|c|c|c|c|c|}
\hline Nutrition Facts & Beetroot & Mulberry Leaves & Nettle Leaves & Rosehip Fruit \\
\hline Moisture (\%) & $3.07 \pm 0.03$ & $3.26 \pm 0.04$ & $3.51 \pm 0.08$ & $3.24 \pm 0.05$ \\
\hline Protein $\left(\mathrm{g} \cdot 100 \mathrm{~g}^{-1}\right)$ & $4.31 \pm 0.11$ & $3.42 \pm 0.09$ & $5.28 \pm 0.13$ & $3.93 \pm 0.07$ \\
\hline Fat $\left(\mathrm{g} \cdot 100 \mathrm{~g}^{-1}\right)$ & $1.42 \pm 0.02$ & $1.15 \pm 0.02$ & $1.39 \pm 0.03$ & $0.98 \pm 0.02$ \\
\hline Sucrose $\left(g \cdot 100 \mathrm{~g}^{-1}\right)$ & $31.66 \pm 0.29$ & $9.96 \pm 0.13$ & $5.57 \pm 0.09$ & $18.57 \pm 0.14$ \\
\hline Glucose $\left(\mathrm{g} \cdot 100 \mathrm{~g}^{-1}\right)$ & $1.27 \pm 0.02$ & $1.41 \pm 0.05$ & $1.39 \pm 0.03$ & $9.13 \pm 0.12$ \\
\hline Fructose $\left(\mathrm{g} \cdot 100 \mathrm{~g}^{-1}\right)$ & $<0.02$ & $0.53 \pm 0.02$ & $1.50 \pm 0.03$ & $11.08 \pm 0.10$ \\
\hline Total sugar $\left(\mathrm{g} \cdot 100 \mathrm{~g}^{-1}\right)$ & $32.92 \pm 0.20$ & $11.89 \pm 0.17$ & $8.46 \pm 0.14$ & $38.08 \pm 0.24$ \\
\hline $\mathrm{K}\left(\mathrm{mg} \cdot 100 \mathrm{~g}^{-1}\right)$ & $2500.01 \pm 38.2$ & $1630.14 \pm 29.3$ & $2950.25 \pm 41.3$ & $2630.46 \pm 40.0$ \\
\hline $\mathrm{Ca}\left(\mathrm{mg} \cdot 100 \mathrm{~g}^{-1}\right)$ & $220.03 \pm 9.20$ & $2870.08 \pm 36.7$ & $2680.16 \pm 35.6$ & $590.33 \pm 11.15$ \\
\hline $\mathrm{P}\left(\mathrm{mg} \cdot 100 \mathrm{~g}^{-1}\right)$ & $410.22 \pm 13.2$ & $430.88 \pm 10.2$ & $770.47 \pm 16.1$ & $690.81 \pm 14.31$ \\
\hline $\operatorname{Mg}\left(\mathrm{mg} \cdot 100 \mathrm{~g}^{-1}\right)$ & $170.06 \pm 12.00$ & $270.68 \pm 9.21$ & $430.58 \pm 14.5$ & $340.66 \pm 10.0$ \\
\hline $\mathrm{Fe}\left(\mathrm{mg} \cdot 100 \mathrm{~g}^{-1}\right)$ & $3.81 \pm 0.07$ & $7.93 \pm 0.11$ & $13.25 \pm 0.41$ & $7.52 \pm 0.13$ \\
\hline $\mathrm{Zn}\left(\mathrm{mg} \cdot 100 \mathrm{~g}^{-1}\right)$ & $2.43 \pm 0.04$ & $2.73 \pm 0.09$ & $3.34 \pm 0.19$ & $2.55 \pm 0.17$ \\
\hline $\mathrm{B}\left(\mathrm{mg} \cdot 100 \mathrm{~g}^{-1}\right)$ & $1.99 \pm 0.01$ & $2.71 \pm 0.03$ & $3.28 \pm 0.04$ & $3.19 \pm 0.04$ \\
\hline $\operatorname{Mn}\left(\mathrm{mg} \cdot 100 \mathrm{~g}^{-1}\right)$ & $1.49 \pm 0.02$ & $1.82 \pm 0.03$ & $1.93 \pm 0.03$ & $1.73 \pm 0.02$ \\
\hline Total phenolic $\left(\mathrm{mg} \cdot 100 \mathrm{~g}^{-1}\right)$ & $224.69 \pm 7.13$ & $301.94 \pm 8.99$ & $313.46 \pm 12.58$ & $461.94 \pm 14.31$ \\
\hline
\end{tabular}

Table 2. Nutrition facts of Greek-style yogurt.

\begin{tabular}{cc}
\hline Nutrition Facts & As Sold for $\mathbf{1 0 0} \mathbf{g}$ \\
\hline Energy (kcal) & 121 \\
Fat (g) & 10 \\
Saturated fat (g) & 6.5 \\
Carbohydrates (g) & 4.0 \\
Sugars (g) & 4.0 \\
Proteins (g) & 3.7 \\
Salt (g) & 0.1 \\
\hline
\end{tabular}

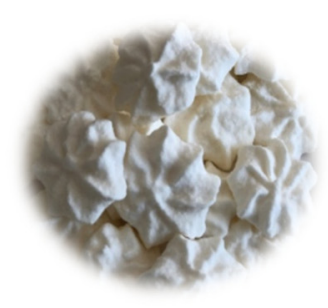

1
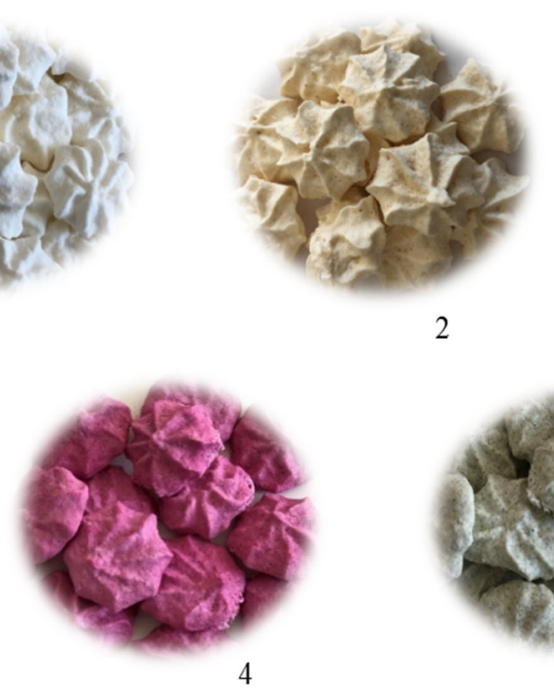

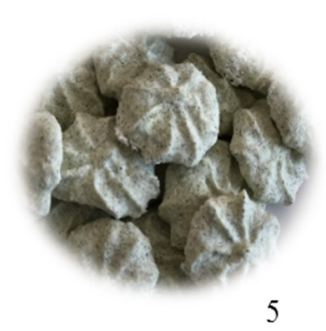

Figure 1. Yogurt bites: yogurt bites without plant raw materials (control) (1); yogurt bites with 1\% rosehip fruit powder (2); yogurt bites with 1\% nettle leaves powder (3); yogurt bites with $1 \%$ beetroot powder (4); yogurt bites with 1\% mulberry leaves powder (5).

To prepare yogurt bites, Greek yogurt, plant raw material powder, fruit pectin, corn starch and maltodextrin were mixed in a mixer until a smooth mixture was obtained. The obtained yogurt samples of $7 \mathrm{~mL}$ of yoghurt were poured into silicone moulds and frozen to $-36{ }^{\circ} \mathrm{C}$ overnight before being transferred to the freeze dryer. After $24 \mathrm{~h}$, the samples were lyophilised using a Freeze-Drying Plant Sublimator $3^{\prime} 4^{\prime} 5$ (ZIRBUS Technology GmbH, 
Bd Grund, Harz, Germany). The samples were transferred to the freeze dryer operating at $-40{ }^{\circ} \mathrm{C}$ in a condensation chamber under vacuum at a minimum pressure of $0.011 \mathrm{kPa}$ and maintained during freeze-drying. The freeze-drying was completed in $72 \mathrm{~h}$. The resultant bites were kept in zip-lock plastic bags until chemical analyses were established. For yogurt bites' quality, laboratory analyses of $500 \mathrm{~g}$ (165 bites) of final lyophilised product were prepared from each treatment. All the chemical analyses were replicated tree times.

\subsection{Proximate Composition Analysis}

The amounts of total sugar in plant raw materials and yogurt bites were identified using a standard enzymatic assay (second method) [26]. The total fat in yogurt bites and plant raw materials was established by the Soxhlet extraction method using SOXTHERM (Gerhardt, GmbH \& Co., Königswinter, Germany) according to AOAC932.06/2012 [27], and the total protein by the Kjeldahl method according to EN ISO 8968-3:2007 using KJELDATHERM (Gerhardt, Königswinter, Germany) [28]. Total carbohydrates were determined by calculating the percentage remaining after all the other components were measured.

\subsection{Mineral Elements Analysis}

Mineral contents $(\mathrm{K}, \mathrm{Ca}, \mathrm{P}, \mathrm{Mg}, \mathrm{Fe}, \mathrm{Zn}, \mathrm{B}, \mathrm{Mn})$ in plant raw materials and yogurt bite samples were carried out using a CEM MARS $6^{\circledR}$ (CEM Corporation, Matthews, NC, USA) digestion system equipped with $100 \mathrm{~mL}$ Teflon vessel. Approximately $0.3 \mathrm{~g}$ of the homogenised sample was accurately weighed into a Teflon vessel and digested using a nitric (HNO3) and hydrochloric $(\mathrm{HCl})$ acid mixture (5:1). Digestion was performed under the following conditions: temperature $-180{ }^{\circ} \mathrm{C}$; pressure $-800 \mathrm{psi}$; ramp time $-20 \mathrm{~min}$; hold time $-20 \mathrm{~min}$; microwave power- $800 \mathrm{~W}$. The digested sample was cooled down and thoroughly transferred into a $100 \mathrm{~mL}$ volumetric flask and diluted using bidistilled water till the mark. Each sample was prepared in triplicate and the blank sample was included in each digestion run. Qualitative and quantitative evaluation of elements was performed using an inductively coupled plasma mass spectrometer (ICP-MS). Inductively coupled plasma mass spectrometry was performed under a helium collision cell (He-cell) with kinetic energy discrimination mode to remove polyatomic interferences. Samples were introduced using an autosampler with ASXpress. A rapid uptake module (CETAC ASX520, Teledyne Technologies Inc., Omaha, NE, USA) through a PEEK nebuliser (Burgener Mira Mist, Burgener Research Inc., Mississauga, Canada) was used. The standard mixture solution of multiple mineral elements in $2 \%$ nitric acid was obtained from CPAchem (Bulgaria). Bidistilled water was prepared by means of distillation apparatus from Thermo Scientific (Fremont, CA, USA). The limits of detection (LOD) and quantification (LOQ) are shown in Table 3.

Table 3. LOD and LOQ $\left(\mathrm{mg} \cdot \mathrm{kg}^{-1}\right)$.

\begin{tabular}{ccc}
\hline Elements & LOD & LOQ \\
\hline $\mathrm{K}$ & 0.0027 & 0.009 \\
$\mathrm{Ca}$ & 0.0056 & 0.0187 \\
$\mathrm{P}$ & 0.01 & 0.033 \\
$\mathrm{Mg}$ & 0.01 & 0.033 \\
$\mathrm{Fe}$ & 0.0155 & 0.0511 \\
$\mathrm{Zn}$ & 0.008 & 0.264 \\
$\mathrm{~B}$ & 0.0231 & 0.106 \\
$\mathrm{Mn}$ & 0.0042 & 0.0138 \\
\hline
\end{tabular}

\subsection{Determination of Total Phenolic Content}

Total phenolic compound content was measured by the spectrophotometric method using Folin-Ciocalteu reagent [29]. In this study, $0.25 \mathrm{~g}$ freeze-dried plant raw materials or yogurt bite samples were mixed with $10 \mathrm{~mL}$ ethanol $(70 \% \mathrm{v} / \mathrm{v})$ and extracted in an ultrasonic bath for $30 \mathrm{~min}$. Then, the extract was centrifuged at $3000 \mathrm{rpm}$ for $30 \mathrm{~min}$. 
Next, $0.2 \mathrm{~mL}$ prepared extract was mixed with $1 \mathrm{~mL}$ Folin-Ciocalteu reagent, $0.8 \mathrm{~mL}$ sodium carbonate $(7 \%)$ and $5 \mathrm{~mL}$ pure water. After $60 \mathrm{~min}$ of incubation at $20^{\circ} \mathrm{C}$ in the dark, the absorbance was measured at $760 \mathrm{~nm}$ using a spectrophotometer (Labomed Inc., Los Angeles, CA, USA). Total phenolic content was measured with the calibration curve using gallic acid equivalent standards. The results were expressed in milligrams per $100 \mathrm{~g}$ of dry matter (mg. $\left.100 \mathrm{~g}^{-1} \mathrm{DM}\right)$.

\subsection{Statistical Analysis}

Data on the proximate and mineral composition of yogurt bites were processed by Microsoft ${ }^{\circledR}$ Excel $^{\circledR} 2016$ MSO software and the Statistica 10 (StatSoft, Inc., Tulsa, OK, USA) package. The reliability of the results was evaluated by one-way analysis of variance, using the ANOVA software package. The statistical significance of differences between the means was estimated by Tukey's test $(p<0.05)$.

\section{Results and Discussion}

\subsection{Proximate Composition}

The proximate composition such as moisture, protein, carbohydrates and fat of all yogurt bite samples is summarised in Table 4 . In this study, the amount of moisture varied from 4.13 to $4.76 \%$ (Table 4 ). The significantly highest moisture amount was found in yogurt bites enriched with rosehip fruit powder, in comparison with all yogurt samples. Among all investigated yogurt bites, the highest amount of total protein was determined for yogurt bites with nettle leaves, followed by the yogurt bites with beetroot, control bites and yogurt bites with mulberry leaves $\left(14.13,13.84,13.72\right.$ and $13.57 \mathrm{~g} \cdot 100 \mathrm{~g}^{-1}$, respectively). Our data showed that total protein amount was established $4.88 \%$ lower in the yogurt bites enriched with rosehip powder compared with the control. In addition, all different raw material powder additives used in the yogurt bites had no significant influence on carbohydrates and total fat amounts. Our investigated plant raw material powders (rosehip fruit, beetroot, mulberry leaves and nettle leaves) are not rich in proximate compounds (protein, carbohydrates and fat) (Table 1). Agustini and other researchers [30] established that the additive of spirulina powder to yogurt samples had significant differences in protein, but no significant differences in moisture or carbohydrate compared to control. Addition of freeze-dried raw material powder did not significantly affect the energy amount of yogurt bites, which ranged from 527 to $534 \mathrm{kcal}$. Similar results were determined by Barakat et al. [31], confirming that proximate chemical composition of pumpkin yoghurt by adding different pumpkin pulps had no significant impact on caloric values. Additionally, similar findings were reported by several other researchers [32-34].

Table 5 shows that the amount of sucrose was found to range from 19.25 to $21.29 \mathrm{~g} \cdot 100 \mathrm{~g}^{-1}$ in all investigated yogurt bites, and the maximum amount of sucrose was established in yogurt bites with beetroot powder. According to the literature, fresh beet/beet powder or extracted pigments are used to improve the red colour of sauces, desserts, sweets, jams, jellies, soups and ice cream [35,36]. As can be seen in Table 1, the highest amount of sucrose was found in beetroot powder (31.66 g.100 g $\mathrm{g}^{-1}$ ). Bavec and other authors [17] have also established that the main sugar in beetroot was sucrose, followed by small amounts of glucose and fructose. Data showed that beetroot additive significantly increased sucrose amount in yogurt bites by as much as $7.24 \%$, compared with the control.

Among all our investigated yogurt bites was established the significantly highest glucose and fructose amounts in yogurt bites enriched with rosehip fruit powder (2.34 and $1.46 \%$, respectively). Additionally, by 1.18 times, the significantly highest total sugar amount was established in bites enriched with rosehip fruit, compared with the control product. It could be due to rosehip fruit powder having the highest amount of total sugar (38.08 g.100 g-1) compared with other investigated raw materials (Table 1). A lesser amount of total sugar in rosehips $\left(8.68-22.44 \mathrm{~g} \cdot 100 \mathrm{~g}^{-1}\right.$ ) has been reported by Kadakal et al. [37]. Therefore, there were no significant differences of total sugar between our other investigated samples (Table 5). According to the literature, sugars are the most 
common soluble constituents of berries and fruit. These sugars have an important effect on taste, nutritive properties and shelf life, and they are acceptable by consumers [38]. Moreover, sugars participate in polyphenol biosynthesis [39]; thus, higher sugar content in fruit implies higher polyphenol concentration [40], and the same is confirmed by the data of our study, where rosehip fruit powder was used as an additive in the production of yogurt bites (Table 5).

Table 4. Proximate composition of yogurt bites.

\begin{tabular}{|c|c|c|c|c|c|c|}
\hline & Control & YBB & YBM & YBN & YBR & $p$-Values \\
\hline Moisture (\%) & $4.31 \pm 0.11 \mathrm{~b}^{1}$ & $4.13 \pm 0.11 b$ & $4.31 \pm 0.12 \mathrm{~b}$ & $4.23 \pm 0.13 b$ & $4.76 \pm 0.23 \mathrm{a}$ & 0.0035 \\
\hline Protein $\left(\mathrm{g} \cdot 100 \mathrm{~g}^{-1}\right)$ & $13.72 \pm 0.22 \mathrm{ab}$ & $13.84 \pm 0.27 \mathrm{a}$ & $13.57 \pm 0.32 \mathrm{ab}$ & $14.13 \pm 0.26 \mathrm{a}$ & $13.05 \pm 0.15 b$ & 0.5400 \\
\hline Carbohydrates $\left(\mathrm{g} \cdot 100 \mathrm{~g}^{-1}\right)$ & $46.66 \pm 0.61 \mathrm{a}$ & $45.94 \pm 0.83 \mathrm{a}$ & $46.66 \pm 1.04 \mathrm{a}$ & $46.18 \pm 0.71 \mathrm{a}$ & $46.77 \pm 1.03 \mathrm{a}$ & 0.0044 \\
\hline Total fat $\left(\mathrm{g} \cdot 100 \mathrm{~g}^{-1}\right)$ & $32.00 \pm 0.67 \mathrm{a}$ & $32.80 \pm 0.85 \mathrm{a}$ & $32.00 \pm 0.73 \mathrm{a}$ & $32.00 \pm 0.95 \mathrm{a}$ & $32.00 \pm 1.01 \mathrm{a}$ & 0.7152 \\
\hline Energy (kcal) & $530 \pm 5.31 \mathrm{a}$ & $534 \pm 6.32 \mathrm{a}$ & $529 \pm 4.99 a$ & $529 \pm 4.16 \mathrm{a}$ & $527 \pm 5.11 \mathrm{a}$ & 0.5752 \\
\hline Energy $(\mathrm{kJ})$ & $2210 \pm 15.02 \mathrm{a}$ & $2230 \pm 14.21 \mathrm{a}$ & $2208 \pm 8.30 \mathrm{a}$ & $2209 \pm 10.23 \mathrm{a}$ & $2201 \pm 6.30 \mathrm{a}$ & 0.0855 \\
\hline
\end{tabular}

${ }^{1}$ Different letters in the same line represent significant differences between samples $(p<0.05)$. Control一yogurt bites without plant raw materials, YBB-yogurt bites with 1\% beetroot powder, YBM-yogurt bites with 1\% mulberry leaves powder, YBN-yogurt bites with $1 \%$ nettle leaves powder, YBR-yogurt bites with 1\% rosehip fruit powder.

Table 5. The sugar content of yogurt bites, $\mathrm{g} \cdot 100 \mathrm{~g}^{-1}$.

\begin{tabular}{ccccccc}
\hline & Control & YBB & YBM & YBN & YBR & $p$-Values \\
\hline Sucrose & $19.75 \pm 0.70 \mathrm{~b}^{1}$ & $21.29 \pm 0.79 \mathrm{a}$ & $20.09 \pm 0.81 \mathrm{~b}$ & $19.21 \pm 0.62 \mathrm{~b}$ & $20.49 \pm 0.65 \mathrm{~b}$ & 0.0463 \\
Glucose & $0.63 \pm 0.05 \mathrm{c}$ & $0.74 \pm 0.05 \mathrm{c}$ & $0.52 \pm 0.06 \mathrm{c}$ & $1.20 \pm 0.08 \mathrm{~b}$ & $2.34 \pm 0.23 \mathrm{a}$ & $<0.0001$ \\
Fructose & $0.21 \pm 0.03 \mathrm{~b}$ & $0.08 \pm 0.01 \mathrm{c}$ & $0.25 \pm 0.04 \mathrm{~b}$ & $0.23 \pm 0.03 \mathrm{~b}$ & $1.46 \pm 0.22 \mathrm{a}$ & $<0.0001$ \\
Total sugars & $20.59 \pm 0.99 \mathrm{~b}$ & $21.37 \pm 0.96 \mathrm{~b}$ & $20.86 \pm 0.85 \mathrm{~b}$ & $20.64 \pm 0.88 \mathrm{~b}$ & $24.29 \pm 1.03 \mathrm{a}$ & 0.0031 \\
\hline
\end{tabular}

${ }^{1}$ Different letters in the same line represent significant differences between samples $(p<0.05)$. Control—yogurt bites without plant raw materials, YBB-yogurt bites with 1\% beetroot powder, YBM-yogurt bites with 1\% mulberry leaves powder, YBN-yogurt bites with $1 \%$ nettle leaves powder, YBR-yogurt bites with 1\% rosehip fruit powder.

\subsection{Mineral Composition}

A macro- and micro-element amount of yogurt is directly related to the original milk used for the production of these products. The mineral composition of milk and yogurt does not change during fermentation [41]. Yogurt is a nutrient-dense food that is an excellent source of some minerals such as calcium, magnesium, phosphorus and so on. These essential micronutrients have a positive influence on human health, especially decreasing the risk of diseases. Their deficiency causes various health disorders such as mental retardation, learning disabilities, blindness, low work efficiency as well as early death [42,43]. Increasing essential micronutrient bioavailability results in improving the society's healthcare $[43,44]$. Various strategies such as yogurt product enrichment with plant raw materials and freeze-drying of final product may be employed to reach this purpose. Therefore, one of the aims of this study was to manufacture novel yogurt products with a higher amount of minerals by combining different freeze-dried raw material powder. Furthermore, there is little information available in the literature regarding the macro- and micro-element amounts of freeze-dried yogurt bites.

The mineral element amounts of yogurt bites are depicted in Table 6. The average amount of mineral elements can be represented as $\mathrm{K}>\mathrm{Ca}>\mathrm{P}>\mathrm{Mg}>\mathrm{Fe}>\mathrm{Zn}>$ $\mathrm{B}>\mathrm{Mn}$. Results showed that of the studied minerals, $\mathrm{K}$ has the highest amount in all samples, ranging from $315.70 \mathrm{mg} \cdot 100 \mathrm{~g}^{-1}$ in yogurt bites without plant raw materials to $603.30 \mathrm{mg} \cdot 100 \mathrm{~g}^{-1}$ in yogurt bites with $1 \%$ nettle leaves powder. Yogurt bites enriched with different plant raw material powders had significantly higher amounts of this element by 38.09-91.10\% compared with the control. The highest $\mathrm{K}$ amount was determined for yogurt bites enriched with nettle leaves powder $\left(603.30 \mathrm{mg} \cdot \mathrm{kg}^{-1}\right)$, and the yogurt bites with rosehip fruit powder showed the second highest amounts of this element $\left(546.22 \mathrm{mg} \cdot \mathrm{kg}^{-1}\right)$. As can be seen in Table 2, freeze-dried nettle leaves powder contained the highest amount of $\mathrm{K}$, followed by the rosehip fruit, beetroot powder and mulberry leaves. According 
to the literature, nettle leaves [11] and rosehip fruit [45] are excellent additives for the development of enriched foods with an increased amount of potassium. The amount of $\mathrm{K}$ can range from 2590 to $3600 \mathrm{mg} \cdot 100 \mathrm{~g}^{-1}$ for nettle leaves [46] and from 1110 to $4540 \mathrm{mg} \cdot 100 \mathrm{~g}^{-1}$ for rosehip fruit [47]. The recommended daily allowance (RDA) for $\mathrm{K}$ is set at $2000 \mathrm{mg} /$ day for adults [48]. Assuming a yogurt bites intake of $100 \mathrm{~g} /$ day, the nettle powder enrichment bites supply the $30.17 \%$, the rosehip powder enrichment bites- $27.31 \%$ of K RDA. The yogurt bites with beetroot $\left(435.94 \mathrm{mg} \cdot 100 \mathrm{~g}^{-1}\right)$ and mulberry leaves $\left(445.20 \mathrm{mg} \cdot 100 \mathrm{~g}^{-1}\right)$ powders exhibited similar amounts of this mineral, where no difference was found (approx. 22\% of recommended daily intake, respectively).

Table 6. Mineral element composition of yogurt bites, $\mathrm{mg} \cdot 100 \mathrm{~g}^{-1}$.

\begin{tabular}{|c|c|c|c|c|c|c|}
\hline $\begin{array}{l}\text { Mineral } \\
\text { Elements }\end{array}$ & Control & YBB & YBM & YBN & YBR & $p$-Values \\
\hline K & $315.70 \pm 6.41 \mathrm{~d}^{1}$ & $435.94 \pm 9.04 c$ & $445.20 \pm 5.00 \mathrm{c}$ & $603.30 \pm 35.03 a$ & $546.22 \pm 5.74 b$ & $<0.0001$ \\
\hline $\mathrm{Ca}$ & $198.78 \pm 4.74 \mathrm{~d}$ & $213.83 \pm 5.20 c$ & $240.81 \pm 3.32 \mathrm{a}$ & $226.24 \pm 2.00 \mathrm{~b}$ & $186.21 \pm 3.40 \mathrm{~d}$ & $<0.0001$ \\
\hline $\mathrm{P}$ & $146.70 \pm 2.39 \mathrm{e}$ & $160.73 \pm 4.21 \mathrm{~d}$ & $202.57 \pm 2.61 c$ & $255.50 \pm 3.60 \mathrm{a}$ & $241.52 \pm 5.53 b$ & $<0.0001$ \\
\hline $\mathrm{Mg}$ & $14.52 \pm 1.51 \mathrm{e}$ & $24.80 \pm 2.50 \mathrm{~d}$ & $34.80 \pm 1.09 c$ & $51.93 \pm 1.12 \mathrm{a}$ & $40.28 \pm 1.39 \mathrm{~b}$ & $<0.0001$ \\
\hline $\mathrm{Fe}$ & $1.98 \pm 0.04 \mathrm{~d}$ & $2.35 \pm 0.16 c$ & $3.30 \pm 0.14 b$ & $5.29 \pm 0.26 \mathrm{a}$ & $3.53 \pm 0.19 b$ & $<0.0001$ \\
\hline $\mathrm{Zn}$ & $1.82 \pm 0.02 \mathrm{~d}$ & $2.27 \pm 0.12 c$ & $2.54 \pm 0.09 \mathrm{~b}$ & $3.08 \pm 0.17 \mathrm{a}$ & $2.73 \pm 0.13 b$ & $<0.0001$ \\
\hline B & $0.09 \pm 0.008 c$ & $0.23 \pm 0.02 \mathrm{~b}$ & $0.23 \pm 0.03 b$ & $0.32 \pm 0.02 \mathrm{a}$ & $0.29 \pm 0.02 \mathrm{a}$ & $<0.0001$ \\
\hline Mn & $0.03 \pm 0.036 \mathrm{c}$ & $0.14 \pm 0.006 \mathrm{~b}$ & $0.11 \pm 0.03 \mathrm{~b}$ & $0.20 \pm 0.01 \mathrm{a}$ & $0.23 \pm 0.03 a$ & $<0.0001$ \\
\hline
\end{tabular}

${ }^{1}$ Different letters in the same line represent significant differences between samples $(p<0.05)$. Control—yogurt bites without plant raw materials, YBB-yogurt bites with 1\% beetroot powder, YBM-yogurt bites with 1\% mulberry leaves powder, YBN-yogurt bites with $1 \%$ nettle leaves powder, YBR-yogurt bites with 1\% rosehip fruit powder.

Calcium and phosphorus are other important minerals found in yogurt bites. Significantly, the highest amount of Ca was found for the sample containing mulberry leaves at $240.81 \mathrm{mg} \cdot 100 \mathrm{~g}^{-1}$, while the control sample $\left(198.78 \mathrm{mg} \cdot 100 \mathrm{~g}^{-1}\right)$ and yogurt bites with rosehip fruit (186.21 mg.100 g ${ }^{-1}$ ) exhibited the lowest amount. As is obvious in Table 1, mulberry leaves powder had the highest amount of Ca $\left(2870.08 \mathrm{mg} \cdot 100 \mathrm{~g}^{-1}\right)$, followed by the nettle leaves $\left(2680.16 \mathrm{mg} \cdot 100 \mathrm{~g}^{-1}\right)$, rosehip fruit $\left(590.33 \mathrm{mg} \cdot 100 \mathrm{~g}^{-1}\right)$ and beetroot $\left(220.03 \mathrm{mg} \cdot 100 \mathrm{~g}^{-1}\right.$ ) powders. From these results, it follows that mulberry leaves as well as nettle leaves are excellent food resources with high amounts of macronutrients such as calcium. Previous research showed that the amount of Ca can range widely from 1121 to $2924 \mathrm{mg} \cdot \mathrm{kg}^{-1}$ in mulberry leaves [49] and from 2210 to $3050 \mathrm{mg} \cdot \mathrm{kg}^{-1}$ in nettle leaves [46]. The RDA is $800 \mathrm{mg} /$ day for Ca in adults [48]. Therefore, the consumption of $100 \mathrm{~g} /$ day of yogurt bites enriched with mulberry leaves supplies $30.10 \%$ of the RDA for $\mathrm{Ca}$. The $\mathrm{Ca}$ in $100 \mathrm{~g}$ of yogurt bites with nettle leaves supplies $28.28 \%$ of the RDA. Maietti et al. [50] also stated that the addition of nettle to bread can significantly increase the content of calcium. Statistical analysis demonstrated that the differences in the amount of P among all yogurt samples were statistically significant. The maximum amount of $\mathrm{P}$ was found for yogurt bites with nettle leaves, followed by the yogurt bites with rosehip fruit, yogurt bites with mulberry leaves and yogurt bites with beetroot at 255.50, 241.52, 202.57 and $160.73 \mathrm{mg} \cdot 100 \mathrm{~g}^{-1}$, respectively. The control sample showed the lowest $\mathrm{P}$ amount $\left(146.70 \mathrm{mg} \cdot 100 \mathrm{~g}^{-1}\right)$. The researchers reported that high amounts in P allow the classification of nettle leaves being the food able to bring supplements with this mineral [10]. The amount of $\mathrm{P}$ in nettle leaves can range between 719 to $1002 \mathrm{mg} \cdot 100 \mathrm{~g}^{-1}$ [46]. Rosehip fruits are also considered an important source of $P$ and its amount can vary widely depending on the genotype [47]. The RDA for P is set at $700 \mathrm{mg} /$ day for adults [48]. Therefore, $100 \mathrm{~g}$ of yogurt bites enriched with nettle powder and yogurt bites enriched with rosehip fruit powder can be particularly considerable sources of $\mathrm{P}$, providing $36.50 \%$ and $34.43 \%$ of the RDA.

The results of this study indicated that the incorporation of different plant raw material powder in yogurt bites allowed the increase of the Mg amount of the manufactured product by 1.71 to 3.58 times. The Mg amount was minimum in yogurt bites without plant raw 
materials (14.52 mg.100 $\left.\mathrm{g}^{-1}\right)$, whereas the maximal amount was determined for yogurt bites with $1 \%$ nettle leaves powder $\left(51.93 \mathrm{mg} \cdot 100 \mathrm{~g}^{-1}\right)$, followed by the yogurt bites with rosehip fruit $\left(40.28 \mathrm{mg} \cdot 100 \mathrm{~g}^{-1}\right)$. According to the literature, both rosehip fruits and nettle leaves accumulate quite similar amounts of this mineral. The $\mathrm{Mg}$ can vary from 420 to $810 \mathrm{mg} \cdot 100 \mathrm{~g}^{-1}$ for nettle leaves [46] and from 430 to $690 \mathrm{mg} \cdot 100 \mathrm{~g}^{-1}$ for rosehip fruit [45]. The RDA for magnesium is $375 \mathrm{mg} /$ day for adults [48]. The consumption of $100 \mathrm{~g} /$ day of yogurt bites enriched with nettle leaves supplies the $13.85 \%$ of the $\mathrm{Mg}$ RDA, while $100 \mathrm{~g}$ of control sample-only $3.87 \%$ of the Mg RDA.

The addition of freeze-dried raw material powders to the formulation of yogurt bites allowed the significant increase in the tested amount of microelements (Fe, Zn, B, Mn) of the final products. The sample enriched with freeze-dried raw material powders contained 18.79-167.17\% higher values of Fe and 24.67-69.23\% more Zn than the yogurt bites without additives. The yogurt bites enriched with nettle leaves powder had the significantly highest amounts of Fe and $\mathrm{Zn}$ (5.29 and $3.08 \mathrm{mg} \cdot 100 \mathrm{~g}^{-1}$, respectively), and the yogurt bites with rosehip fruit powder showed the second highest amounts of both these elements (Fe$\left.3.53 \mathrm{mg} \cdot \mathrm{kg}^{-1}, \mathrm{Zn}-2.73 \mathrm{mg} \cdot 100 \mathrm{~g}^{-1}\right)$. In yogurt bites, the B amount varied from 0.09 to $0.32 \mathrm{mg} \cdot 100 \mathrm{~g}^{-1}$, and the Mn amount ranged from 0.03 to $0.23 \mathrm{mg} \cdot 100 \mathrm{~g}^{-1}$. The yogurt bites with nettle leaves and rosehip fruit powders showed the significantly highest amounts of B and Mn. These values were not significantly different at $p<0.05$. The samples with beetroot and mulberry leaves powders exhibited similar amounts of both these minerals, where no difference was found. The lowest amounts of Fe, Zn, B and Mn were determined for the control yogurt sample. As can be seen in Table 1, freeze-dried nettle leaves powder is rich in Fe, $\mathrm{Zn}, \mathrm{B}$ and $\mathrm{Mn}$. Due to this reason, nettle leaves can be used as an ingredient in foods and beverages. The RDAs are $14 \mathrm{mg} /$ day for Fe, $10 \mathrm{mg} /$ day for $\mathrm{Zn}$ and $2 \mathrm{mg} \mathrm{Mn}$ in adults [48]. Therefore, the consumption of $100 \mathrm{~g}$ of the nettle powder enrichment bites would supply $37.79 \%$ of the RDA for Fe, 30.80\% of the RDA for Zn and $10 \%$ of the RDA for $\mathrm{Mn}$, while $100 \mathrm{~g}$ of the control sample would account for $14.14 \%$ of RDA for Fe, $18.20 \%$ of the RDA for $\mathrm{Zn}$ and $1.5 \%$ of the RDA for Mn. Literature data also confirm that nettle leaves are rich in mineral elements. The amount of these substances is about $20 \%$ of the dry mass. The major microelements in nettle are iron and zinc [51]. The rosehip fruit powder also is rich in minerals such as Fe, Mn and $\mathrm{Zn}$ (Table 1). Assuming a yogurt bites intake of $100 \mathrm{~g} /$ day, the rosehip fruit enrichment bites supply $25.21 \%$ of the RDA for Fe, $27.30 \%$ of the RDA for $\mathrm{Zn}$ and $14.50 \%$ of the RDA for Mn.

\subsection{Total Phenolic Amount}

Regardless that dairy products (including yoghurt and yogurt products) have a high nutritive value, they are poor sources for phenolic compounds. Plants are the major sources of phenolic compounds in the human diet [5]. Therefore, the combination of plant raw materials with various yogurt products could be nutritionally beneficial. Figure 2 shows that yogurt bites enriched with different plant raw material powders had a significantly higher amount of total phenolic content by 1.86-3.54 times compared with the control sample without additives. The highest total phenolic amount was established for yogurt bites enriched with rosehip fruit powder $\left(49.05 \mathrm{mg} \cdot 100 \mathrm{~g}^{-1}\right)$, and the yogurt bites with nettle and mulberry leaves

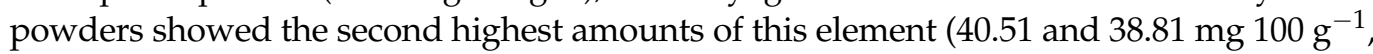
respectively). As illustrated in Table 1, rosehip fruit powder had the highest amount of total phenolic content $\left(461.94 \mathrm{mg} \cdot 100 \mathrm{~g}^{-1}\right)$, followed by the nettle leaves $\left(313.46 \mathrm{mg} \cdot 100 \mathrm{~g}^{-1}\right)$, mulberry leaves $\left(301.94 \mathrm{mg} \cdot 100 \mathrm{~g}^{-1}\right)$ and beetroot $\left(224.69 \mathrm{mg} \cdot 100 \mathrm{~g}^{-1}\right)$ powders.

As our study has shown, these plant raw materials are excellent sources of phenolic compounds for enrichment of yogurt bites. However, there is no information about the effect of plant raw materials used in our study on the amount of total phenolic content of yogurt bites. Rosehip fruits are known as rich in phenolic compounds and their content can range from 130.83 to $766.0 \mathrm{mg} \cdot 100 \mathrm{~g}^{-1} \mathrm{DW}$, depending on species, harvesting time and environmental conditions [52,53]. Previous research has shown that incorporation of rosehip powder in cookies has definitely increased the total phenolic content [54]. A signif- 
icant increment of total phenolic content was also observed in nettle-enriched bread [50], beetroot juice-enriched yogurt [55] and mulberry leaf extract-enriched yogurt [56].

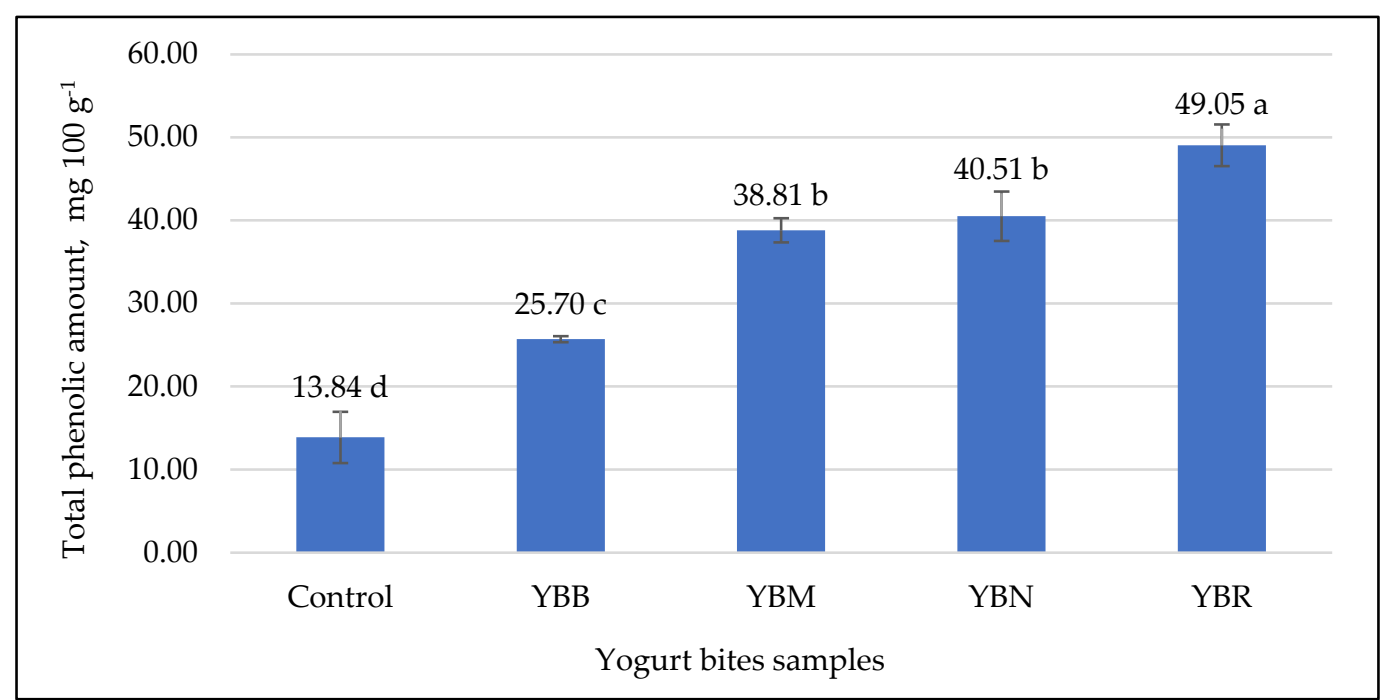

Figure 2. Total phenolic content of yogurt bites, $\mathrm{mg} \cdot 100 \mathrm{~g}^{-1}$. Different letters represent significant differences between samples $(p<0.05)$. Control-yogurt bites without plant raw materials, YBB-yogurt bites with $1 \%$ beetroot powder, YBM-yogurt bites with $1 \%$ mulberry leaves powder, YBN-yogurt bites with $1 \%$ nettle leaves powder, YBR-yogurt bites with $1 \%$ rosehip fruit powder.

\section{Conclusions}

In conclusion, the $1 \%$ powder of raw material additive added to yogurt bites showed no changes on proximate composition, except for the significantly highest moisture and total sugar amounts that were established in yogurt bites enriched with rosehip fruit powder, compared with the control. There were differences in mineral and total phenolic content of yogurt bites enriched with plant raw materials compared to the control. Importantly, $1 \%$ nettle leaves powder additive had significantly increased amounts of $\mathrm{K}, \mathrm{P}, \mathrm{Mg}, \mathrm{Fe}$ and $\mathrm{Zn}$ in yogurt bites followed by the rosehip fruit powder. The study clearly showed that the additive of freeze-dried mulberry leaves powder had a significantly increased $\mathrm{Ca}$ amount of the yogurt bites. The highest amount of total phenolic content was established for yogurt bites enriched with rosehip fruit powder. Therefore, this study revealed that nettle leaves, rosehip fruit, mulberry leaves and beetroot powder additives improve yogurt bites' nutritional value, as well as being a beneficial additive for food production.

Author Contributions: Conceptualisation, J.K., N.V., D.L.; methodology, J.K., N.V., D.L.; software J.K., N.V., D.L.; formal analysis, J.K., N.V., D.L.; investigation, J.K., N.V., D.L.; data curation, J.K., N.V., D.L.; writing-original draft preparation, J.K., N.V., D.L.; writing-review and editing, J.K., N.V., D.L.; visualisation, J.K., N.V., D.L.; supervision J.K; project administration J.K. All authors have read and agreed to the published version of the manuscript.

Funding: This research was funded by the European Structural Fund, within the international project Eureka E!13405 LYBEF “Lyophilized yoghurt bites enriched with non-traditional functional raw materials".

Institutional Review Board Statement: Not applicable.

Informed Consent Statement: Not applicable.

Conflicts of Interest: The authors declare no conflict of interest. 


\section{References}

1. Faccinetto-Beltran, P.; Andrea, R.; Fernández, G.; Santacruz, A.; Daniel, A.; Velázquez, J. Chocolate as Carrier to Deliver Bioactive Ingredients: Current Advances and Future Perspectives. Foods 2021, 10, 2065. [CrossRef] [PubMed]

2. Muehlhoff, E.; Bennett, A.; Mcmahon, D. Milk and Dairy Products in Human Nutrition; Food and Agriculture Organization of the United Nations: Rome, Italy, 2013; pp. 11-35.

3. Rizzoli, R. Dairy products, yogurts, and bone health. Am. J. Clin. Nutr. 2014, 99, 1256S-1262S. [CrossRef]

4. Franzoi, M.; Niero, G.; Penasa, M.; Cassandro, M.; De Marchi, M. Technical note: Development and validation of a new method for the quantification of soluble and micellar calcium, magnesium, and potassium in milk. J. Dairy Sci. 2017, 101, 1883-1888. [CrossRef] [PubMed]

5. O'connell, J.; Fox, P. Significance and applications of phenolic compounds in the production and quality of milk and dairy products: A review. Int. Dairy J. 2001, 11, 103-120. [CrossRef]

6. Jankowska, A.; Reps, A. Factors affecting the shelf-life of yoghurt during storage [Czynniki decydujące o trwałości jogurtu podczas przechowywania]. Prz. Mlecz. 2013, 11, 2-5.

7. Hartl, A.; Vogl, C.R. Dry matter and fiber yields, and the fiber characteristics of five nettle clones (Urtica dioica L.) organically grown in Austria for potential textile use. Altern. Agric. 2002, 17, 195-200.

8. Vogl, C.R.; Hartl, A. Production and processing of organically grown fiber nettle (Urtica dioica L.) and its potential use in the natural textile industry: A review. J. Altern. Agric. 2003, 18, 119-128. [CrossRef]

9. Rafajlovska, V.; Kavrakovski, Z.; Siminovska, J.; Srbinoska, M. Determination of protein and mineral contents in stinging nettle. Qual. Life 2013, 4, 26-30. [CrossRef]

10. Rutto, L.K.; Xu, Y.; Ramirez, E.; Brandt, M. Mineral Properties and Dietary Value of Raw and Processed Stinging Nettle (Urtica dioica L.). Int. J. Food Sci. 2013, 2013, 1-9. [CrossRef] [PubMed]

11. Said, A.A.H.; Otmani, I.S.E.; Derfoufi, S.; Benmoussa, A. Highlights on nutritional and therapeutic value of stinging nettle (Urtica dioica). Int. J. Pharm. Pharm. Sci. 2015, 7, 8-14.

12. Joshi, B.C.; Mukhija, M.; Kalia, A.N. Pharmacognostical review of Urtica dioica L. Int. J. Gren Pharm. 2014, 8, 201-209.

13. Kale, R.G.; Sawate, A.R.; Kshirsagar, R.B.; Patil, B.M.; Mane, R.P. Studies on evaluation of physical and chemical composition of beetroot (Beta vulgaris L.). Int. J. Chem. Stud. 2018, 6, 2977-2979.

14. Neelwarne, B.; Halagur, S.B. Red beet: An overview. In Red Beet Biotechnology—Food and Pharmaceutical Applications; Neelwarne, B., Ed.; Springer Science + Business Media: Berlin/Heidelberg, Germany, 2013; pp. 1-43.

15. Chawla, H.; Parle, M.; Sharma, K.; Yadav, M. Beetroot: A health promoting functional food. Inventi Impact: Nutraceuticals 2016, $1,8-12$.

16. Masih, D.; Singh, N.; Singh, A. Red beetroot: A source of natural colourant and antioxidants: A review. J. Pharmacogn. Phytochem. 2019, 8, 162-166.

17. Bavec, M.; Turinek, M.; Grobelnik, M.S.; Slatnar, A.; Bavec, F. Influence of industrial and alternative farming systems on contents of sugars, organic acids, total phenolic content, and the antioxidant activity of red beet (Beta vulgaris L. ssp. vulgaris). J. Agric. Food Chem. 2010, 58, 11825-11831. [CrossRef]

18. Patel, S. Rose hip as an underutilized functional food: Evidence-based review. Trends Food Sci. Technol. 2017, 63, 29-38. [CrossRef]

19. Kulaitienè, J.; Medveckienè, B.; Levickienė, D.; Vaitkevičienè, N.; Makarevičienè, V.; Jarienè, E. Changes in Fatty Acids Content in Organic Rosehip (Rosa spp.) Seeds during Ripening. Plants 2020, 9, 1793. [CrossRef]

20. Srivastava, S.; Kapoor, R.; Thathola, A.; Srivastava, R.P. Nutritional quality of leaves of some genotypes of mulberry (Morus alba). Int. J. Food Sci. Nutr. 2006, 57, 305-313. [CrossRef]

21. Butt, M.S.; Nazir, A.; Sultan, T.M.; Schoën, K. Morus alba L. nature's functional tonic. Trends Food Sci. Technol. 2008, 19, 505-512. [CrossRef]

22. Adeduntan, S.A.; Oyerinde, A.S. Evaluation of chemical and antinutritional characteristics of obeche (Triplochition scleroxylon) and some mulberry (Morus alba) leaves. Int. J. Biol. Chem. Sci. 2009, 3, 681-687. [CrossRef]

23. Radojković, M.M.; Zeković, Z.P.; Dojinović, B.P.; Stojanović, Z.S.; Cvetanović, A.D.; Manojlović, D.D. Characterization of Morus species in respect to micro, macro, and toxic elements. Acta Period. Technol. 2014, 45, 229-237. [CrossRef]

24. Levickienè, D.; Vaitkevičienè, N.; Jarienè, E.; Mažeika, R. The content of macroelements in white mulberry (Morus alba L.) leaves. Agric. Sci. 2018, 4, 177-183. [CrossRef]

25. Marschner, H. Mineral Nutrition of Higher Plants, 2nd ed.; Academic Press Inc.: San Diego, CA, USA, 1995.

26. Al-Mhanna, N.M.; Huebner, H.; Buchholz, R. Analysis of the sugar content in food products by using gas chromatography mass spectrometry and enzymatic methods. Foods 2018, 7, 185. [CrossRef]

27. AOAC, Official Method 932.06. Fat in milk powder. In Official Methods of Analysis of AOAC International, 19th ed.; AOAC International: Gaithersburg, MD, USA, 2012.

28. EN ISO 8968-3:2007. Milk-Determination of Nitrogen Content; iTeh Standards: Newark, NJ, USA, 2007.

29. Tamilselvi, N.; Krishnamoorthy, P.; Dhamotharan, R.; Arumugam, P.; Sagadevan, E. Analysis of total phenols, total tannins and screening of phytocomponents in Indigofera aspalathoides (Shivanar Vembu) Vahl EX DC. J. Chem. Pharm. Res. 2012, 4, $3259-3262$.

30. Agustini, T.W.; Soetrisnanto, D.; Ma'ruf, W.F. Study on Chemical, Physical, Microbiological and Sensory of Yoghurt Enriched by Spirulina Platensis. Int. Food Res. J. 2017, 24, 367-371. 
31. Barakat, H.; Hassan, M.F.Y. Chemical, Nutritional, Rheological, and Organoleptical Characterizations of Stirred Pumpkin-Yoghurt. Food Nutr. Sci. 2017, 8, 746-759. [CrossRef]

32. Matter, A.A.; Mahmoud, E.A.M.; Zidan, N.S. Fruit Flavored Yoghurt: Chemical, Functional and Rheological Properties. Int. J. Agric. Environ. Res. 2016, 2, 57-66.

33. Yu, M.S.; Kim, J.M.; Lee, C.H.; Son, Y.J.; Kim, S.K. Quality Characteristics of Stirred Yoghurt Added with Fermented Red Pepper. Korean J. Food Sci. Anim. Resour. 2014, 34, 408-414. [CrossRef]

34. Najgebauer-Lejko, D.; Grega, T.; Tabaszewska, M. Yoghurts with Addition of Selected Vegetables: Acidity, Antioxidant Properties and Sensory Quality. Acta Sci. Pol. Technol. 2014, 13, 35-42. [CrossRef] [PubMed]

35. Koul, V.K.; Jain, M.P.; Koul, S.; Sharma, V.K.; Tikoo, C.L.; Jain, S.M. Spray drying of beet root juice using different carriers. Indian J. Chem. Technol. 2002, 9, 442-445.

36. Roy, K.; Gullapalli, S.; Chaudhuri, U.R.; Chakraborty, R. The use of a natural colorant based on betalain in the manufacture of sweet products in India. Int. J. Food Sci. Technol. 2004, 39, 1087-1091. [CrossRef]

37. Kadakal, C.; Nas, S.; Artik, N. Kusburnu (Rosa canina L.) meyve ve cekirdeginin bilesimi ve insan beslenmesi acisindan onemi. Gida Temmuz-Agustos 2002, 7, 111-117.

38. Akagić, A.; Vranac, A.; Gaši, F.; Drkenda, P.; Spaho, N.; Oručević Žuljević, S.; Kurtović, M.; Musić, O.; Murtić, S.; Hudina, M. Sugars, acids and polyphenols profile of commercial and traditional apple cultivars for processing. Acta Agric. Slov. 2019, 113, 239-251. [CrossRef]

39. Pirie, A.; Mullins, M.G. Interrelationships of sugars, anthocyanins, total phenols and dry weight in the skin of grape berries during ripening. Am. J. Enol. Vitic. 1977, 28, 204-209.

40. Milivojević, J.; Rakonjac, V.; Fotirić Akšić, M.; Bogdanović Pristov, J.; Maksimović, V. Classification and fingerprinting of different berries based on biochemical profiling and antioxidant capacity. Pesqui. Agropecu. Bras. 2013, 48, 1285-1294. [CrossRef]

41. Walstra, P.; Walstra, P.; Wouters, J.T.; Geurts, T.J. Dairy Science and Technology, 2nd ed.; CRC Press: Boca Raton, USA, $2005 ;$ p. 291.

42. Hahsemi Gahruie, H.; Eskandari, M.H.; Mesbahi, G.; Hanifpour, M.A. Scientific and technical aspects of yogurt fortification: A review. Food Sci. Hum. Wellness 2015, 4, 1-8. [CrossRef]

43. Hahsemi Gahruie, H. Yogurt. The most suitable carrier for increasing bioavailability of minerals. Prog. Nutr. 2018, $20,294-296$.

44. Lotfi, M.; Venkatesh Mannar, M.; Merx, R.J.; Heuvel, P.N. Micronutrient Fortification of Foods: Current Practices, Research, and Opportunities; The Micronutrient Initiative: Ottawa, Canada, 1996; p. 106.

45. Bilgin, N.A.; Misirli, A.; Şen, F.; Türk, B.; Yağmur, B. Fruit Pomological, Phytochemical Characteristic and Mineral Content of Rosehip Genotypes. Int. J. Food Eng. 2020, 6, 18-23. [CrossRef]

46. Paulauskienè, A.; Tarasevičienè, Ž.; Laukagalis, V. Influence of Harvesting Time on the Chemical Composition of Wild Stinging Nettle (Urtica dioica L.). Plants 2021, 10, 686. [CrossRef] [PubMed]

47. Ozrenk, K.; Gündoğdu, M.; Doğan, A. Organic acid, sugar and mineral matter contents in rosehip (Rosa canina L.) Fruits of Erzincan Region. YYU J. AGR 2012, 22, 20-25.

48. EU Regulation. No 1169/2011 of the European Parliament and of the Council of 25 October 2011 on the provision of food information to consumers, amending Regulations (EC) No 1924/2006 and (EC) No 1925/2006 of the European Parliament and of the Council, and repealing Commission Directive 87/250/EEC, Council Directive 90/496/EEC, Commission Directive 1999/10/EC, Directive 2000/13/EC of the European Parliament and of the Council, Commission Directives 2002/67/EC and 2008/5/EC and Commission Regulation (EC) No 608/2004. OJEU 2011, 304, 18-63 (BG, ES, CS, DA, DE, ET, EL, EN, FR, IT, LV, LT, HU, MT, NL, PL, PT, RO, SK, SL, FI, SV).

49. Levickienè, D. The Influence of the Biodynamic Preparations on the Soil Properties and Accumulation of Bioactive Compounds in the Leaves of White Mulberry (Morus alba L.). Ph.D. Dissertation, ASU, Kaunas, Lithuania, 2018.

50. Maietti, A.; Tedeschi, P.; Catani, M.; Stevanin, C.; Pasti, L.; Cavazzini, A.; Marchetti, N. Nutrient Composition and Antioxidant Performances of Bread-Making Products Enriched with Stinging Nettle (Urtica dioica) Leaves. Foods 2021, 10, 938. [CrossRef]

51. Pradhan, S.; Manivannan, S.; Tamang, J.P. Proximate, mineral composition and antioxidant properties of some wild leafy vegetables. J. Sci. Ind. Res. 2015, 74, 155-159.

52. Koczka, N.; Stefanovits-Bányai, É.; Ombódi, A. Total polyphenol content and antioxidant capacity of rosehips of some Rosa species. Medicines 2018, 5, 84. [CrossRef] [PubMed]

53. Medveckienè, B.; Kulaitienė, J.; Jarienè, E.; Vaitkevičienè, N.; Hallman, E. Carotenoids, Polyphenols, and Ascorbic Acid in Organic Rosehips (Rosa spp.) Cultivated in Lithuania. Appl. Sci. 2020, 10, 5337. [CrossRef]

54. Antarkar, S.; Sharma, A.; Bhargava, A.; Gupta, H.; Tomar, R.; Srivastava, S. Physico-chemical and nutritional evaluation of cookies with different levels of Rosehip and Hibiscus powder substitution. Arch. Curr. Res. Int. 2019, 17, 1-10. [CrossRef]

55. Flores-Mancha, M.A.; Ruíz-Gutiérrez, M.G.; Sánchez-Vega, R.; Santellano-Estrada, E.; Chávez-Martínez, A. Effect of encapsulated beet extracts (Beta vulgaris) added to yogurt on the physicochemical characteristics and antioxidant activity. Molecules 2021, 26, 4768. [CrossRef]

56. Wang, Y.; Song, K.Y.; Kim, Y. Effects of thermally treated mulberry leaves on the quality, properties, and antioxidant activities of yogurt. J. Food Process. Preserv. 2021, 00, e16139. [CrossRef] 